\title{
Identification, Isolation, and Partial Characterization of a Fatty Acid Binding Protein from Rat Jejunal Microvillous Membranes
}

\author{
Wolfgang Stremmel, Gabriele Lotz, Georg Strohmeyer, and Paul D. Berk \\ Medizinische Klinik D der Universität Düsseldorf, 4000 Dusseldorf, West Germany; and The Polly Annenberg Levee Hematology \\ Center and the Hepatic Research Group (Department of Medicine), Mount Sinai School of Medicine, New York, New York 10029
}

\begin{abstract}
The mechanisms by which FFA are absorbed by the gut are unclear. To examine these processes, binding of $\left[{ }^{14} \mathrm{C}\right]$ oleate to isolated rat jejunal microvillous membranes (MVM) was studied in vitro. When $\left[{ }^{14} \mathrm{C}\right]$ leate alone or compounded with bovine serum albumin at various molar ratios was incubated with MVM aliquots, binding was time- and temperature-dependent, inhibitable by addition of excess cold oleate, and decreased by heat denaturation or trypsin digestion of the membranes. When $\left[{ }^{14}\right.$ C]oleate binding to heat denatured MVM, which increased continuously as a function of the free oleate concentration and was taken as a measure of nonspecific binding, was subtracted from total binding to native MVM, a curve suggestive of saturable specific binding was observed. In contrast to fatty acids, there was no specific binding of $\left[{ }^{14} \mathrm{C}\right]$ taurocholate or ${ }^{35}$ S]sulfobromophthalein to jejunal MVM. After MVM solubilization with $1 \%$ Triton $\mathrm{X}-100$, affinity chromatography over oleate-agarose and elution with $7 \mathrm{M}$ urea yielded a single 40,000-mol-wt protein. This Sudan Black/periodic acid-Schiffstain-negative protein co-chromatographed on Sephadex G100 with $\left[{ }^{14} \mathrm{C}\right]$ leate, $\left[{ }^{14} \mathrm{C}\right]$ palmitate, $\left[{ }^{14} \mathrm{C}\right]$ arachidonate, and $\left[{ }^{14} \mathrm{C}\right]$ linoleate, but not with the $\left[{ }^{14} \mathrm{C}\right]$ oleate ester of cholesterol, $\left[{ }^{14} \mathrm{C}\right]$ phosphatidylcholine, $\left[{ }^{14} \mathrm{C}\right]$ taurocholate, or $\left[{ }^{35}\right.$ S]sulfobromophthalein. A rabbit antibody to the previously reported hepatic membrane fatty acid binding protein (FABP) gave a single line of immunologic identity between the FABPs of rat jejunum and rat liver membrane. It inhibited the binding of $\left[{ }^{14}\right.$ Cloleate to native MVM but not heat denatured MVM, and, in immunohistochemical studies, demonstrated the presence of the FABP in the apical and lateral portions of the brush border cells of the jejunum, but not on the luminal surface of esophagus or colon. These data are compatible with the hypothesis that a specific FABP plays a role in fatty acid absorption from the gut.
\end{abstract}

\section{Introduction}

The mechanisms by which FFA enter the liver cell or are absorbed from the gut are incompletely understood. Although cellular uptake of FFA was long considered a passive, diffusional process, recent studies suggest $(a)$ that fatty acids bind specifically to rat liver plasma membranes $(\mathrm{LPM})^{1}(1) ;(b)$ that such

Address reprint requests to Dr. Wolfgang Stremmel, Medizinische Klinik D der Universität Düsseldorf, 4000 Düsseldorf, West Germany.

Received for publication 23 August 1984 and in revised form 20 November 1984.

1. Abbreviations used in this paper: BSP, $\left[{ }^{35} \mathrm{~S}\right]$ sulfobromophthalein; FABP, fatty acid binding protein; LPM, liver plasma membranes; MVM, microvillous membrane.

J. Clin. Invest.

(c) The American Society for Clinical Investigation, Inc.

0021-9738/85/03/1068/09 \$1.00

Volume 75, March 1985, 1068-1076 binding is attributable to a specific, LPM-fatty acid binding protein (FABP), which has been partially characterized and is distinct from the cytosolic FABP of rat liver and small intestine $(1,2) ;(c)$ that fatty acid uptake in various mammalian cells demonstrates saturation kinetics (3-7) and, in the specific case of the hepatocyte, also demonstrates energy dependence, an association with sodium transport, and inhibition by an antibody to LPM-FABP (8). The preliminary immunohistologic observation that a protein reactive with antibodies to LPMFABP was present on the surface of rat jejunal mucosa raised the question of whether absorption of FFA from the gut may also be mediated by a specific intestinal membrane transport process. Since binding to plasma membranes represents the first step in any cellular uptake mechanism, the aim of this study was to characterize the binding of a representative fatty acid, oleate, to microvillous membranes (MVM) of rat jejunum and to isolate a putative FABP from these membranes.

\section{Methods}

Preparation of $M V M$. MVM-enriched fractions were prepared by a modification of the $\mathrm{Ca}^{2+}$ precipitation procedure $(9,10)$. Three male Sprague-Dawley rats ( $200 \mathrm{~g}$ body wt; Zentralinstitut für Versuchstiere, Hannover, FRG) were starved overnight. After decapitation the intestine was removed, rinsed three times with $20 \mathrm{ml}$ ice-cold saline, and divided approximately into duodenum (first third), jejunum (second third), and ileum (final third). The lumen was opened by a longitudinal section, adherent fat tissue removed, and the mucosa was scraped off gently with a glass slide. Each mucosal scraping was suspended in $\mathbf{3 0 0}$ $\mathrm{ml}$ of $50 \mathrm{mM}$ mannitol- $2 \mathrm{mM}$ Tris/ $\mathrm{HCl}, \mathrm{pH} 7.5$, and homogenized in a Waring blender at full speed for $2.5 \mathrm{~min}$. To each preparation solid $\mathrm{CaCl}_{2}$ was added, while stirring, to a final concentration of $10 \mathrm{mM}$. After standing on ice for $15 \mathrm{~min}$, the suspension was spun down at $4,500 \mathrm{rpm}$ in a GSA rotor (Sorvall RC-5B refrigerated superspeed centrifuge, Du Pont de Nemours, E. I. \& Co., Inc./ Sorvall Instruments Div., Newtown, CT) for $15 \mathrm{~min}$. The supernatant was then centrifuged at $13,000 \mathrm{rpm}$ in the GSA rotor for $30 \mathrm{~min}$. The pellets were resuspended in $80 \mathrm{ml}$ of $100 \mathrm{mM}$ mannitol, $1 \mathrm{mM}$ Tris-Hepes (pH 7.5), $50 \mu \mathrm{l}$ of $0.25 \mathrm{M} \mathrm{MgCl}_{2}$ was added and the suspension evenly homogenized with three strokes of a loosely fitting motor driven Teflon pestle in a 30-ml Thomas homogenizer (Fisher Scientific Co., Allied Corp., Pittsburgh, PA). After centrifugation for $30 \mathrm{~min}$ at $15,000 \mathrm{rpm}$ in an SS-34 rotor (Du Pont de Nemours, E. I. \& Co., Inc.), the pellets were resuspended in $80 \mathrm{ml}$ of $100 \mathrm{mM}$ mannitol, $1 \mathrm{mM}$ Tris-Hepes (pH 7.5) and left standing for $30 \mathrm{~min}$ on ice. After a final centrifugation at $15,000 \mathrm{rpm}$ (in the SS-34 rotor) for $30 \mathrm{~min}$ the pellets were collected in $0.013 \mathrm{M}$ Tris $/ \mathrm{HCl}, \mathrm{pH} 7.5$, and frozen at $-20^{\circ} \mathrm{C}$ until use. All operations were performed at $4^{\circ} \mathrm{C}$.

MVM preparations were characterized by electron microscopy (11) and enzymatic markers. Sucrase activity was determined according to Fujita et al. (12); 5'-nucleotidase and glucose-6-phosphatase were assayed as previously described (13). Membrane preparations were analyzed by double immunodiffusion in agar (14) against antibodies to rat-ligandin (gift of Dr. A. W. Wolkoff, Albert Einstein College of Medicine, New York, NY), -transferrin, -albumin, and to whole rat serum proteins (all from Cappel Laboratories, Cochranville, PA), to detect cytoplasmatic and serum protein contamination. Membrane protein was determined according to the method of Lowry et al. (15). 
Membrane binding studies. $\left[{ }^{14} \mathrm{C}\right]$ Oleate $(900 \mathrm{mCi} / \mathrm{mmol} ; 99 \%$ radiochemically pure; New England Nuclear, Boston, MA) was mixed with known quantities of nonradioactive oleic acid (Sigma Chemical Co., St. Louis, $\mathrm{MO}$ ) in chloroform, dried under an $\mathrm{N}_{2}$ gas stream, and dissolved in $0.2 \mathrm{ml}$ of $0.1 \mathrm{~N} \mathrm{NaOH}$ at $37^{\circ} \mathrm{C}$. After the addition of $0.15 \mathrm{M} \mathrm{NaCl} / 0.02 \mathrm{M}$ phosphate-buffered saline (PBS) and adjusting the $\mathrm{pH}$ to 7.6 the solution was used as described or after further addition of defatted (16) bovine serum albumin (BSA) (fraction V, Sigma Chemical Co.) to achieve oleate/albumin in ratios of 0.1:1-4:1. The freshly prepared $\left[{ }^{14} \mathrm{C}\right]$ oleate solutions were, in all cases, clear, and exhibited no evidence of turbidity or precipitation.

Incubations of $\left[{ }^{14} \mathrm{C}\right]$ oleate $(100-4,500 \mathrm{nM})$, either alone or bound to albumin in various molar ratios, with aliquots of $100 \mu \mathrm{g} \mathrm{MVM}$ protein were carried out in polypropylene tubes at a final volume of $440 \mu \mathrm{l}$ PBS, $\mathrm{pH}$ 7.6. Heat denatured MVM were prepared by incubation for $16 \mathrm{~h}$ at $45^{\circ} \mathrm{C}$; agglutination of membrane particles was avoided. Studies of $\left[{ }^{14} \mathrm{C}\right]$ oleate binding to MVM included the following information: time course of binding; and assessment of temperature dependency at $4^{\circ}, 23^{\circ}, 37^{\circ}$, and $50^{\circ} \mathrm{C}$, and of $\mathrm{pH}$ dependency by varying the $\mathrm{pH}$ of the incubation medium from 2.0 to 9.0 using the citratephosphate-borate/HCl buffer system (17). Saturability of binding was studied by incubation of membrane aliquots with increasing concentrations of $\left[{ }^{14} \mathrm{C}\right]$ oleate $(0.1-4.5 \mu \mathrm{M})$ either alone or bound to BSA in molar ratios of 0.1:1-4:1 (oleate/albumin). For each incubation with native membranes, a comparable study was conducted with heat denatured membranes to provide an estimate of nonspecific binding. Binding to native and heat denatured membranes was plotted as a function of the concentration of free oleate in the incubation mixture at equilibrium. This, in turn, was calculated by the stepwise equilibrium constant method of Wosilait and Nagy (18) using a computer program written by Dr. Luis M. Isola (Mount Sinai School of Medicine, New York, NY), and the dissociation constants for the oleate/BSA complex reported by Spector et al. (19). Heat sensitive (specific) binding was calculated as the difference between binding to native and heat denatured MVM. The effect of trypsin digestion on $\left[{ }^{14} \mathrm{C}\right]$ oleate binding was determined by preincubation of $100 \mu \mathrm{g}$ MVM protein aliquots $(20 \mu \mathrm{l})$ with $200 \mu \mathrm{l}$ of $0.148 \mathrm{mg} / \mathrm{ml}$ trypsin (Sigma Chemical Co.) in 1 $\mathrm{mM}$ Tris/ $\mathrm{HCl}, \mathrm{pH} 8.0$, for $2 \mathrm{~h}$ at $37^{\circ} \mathrm{C}$ and subsequent incubation with $200 \mu \mathrm{l}(1 \mathrm{nmol})$ free $\left[{ }^{14} \mathrm{C}\right]$ oleate in aqueous solution at $\mathrm{pH} 8.0$ and 4.0. In comparative studies binding of $0.5-9 \mu \mathrm{M}$ $\left[{ }^{35}\right.$ S]sulfobromophthalein (BSP) (Amersham Corp., Arlington Heights, IL; $100 \mathrm{mCi} / \mathrm{mmol}$ ) and $0.5-230 \mu \mathrm{M}\left[{ }^{14} \mathrm{C}\right]$ taurocholate (New England Nuclear, $43.3 \mathrm{mCi} / \mathrm{mmol}$ ) to aliquots of $0.1 \mathrm{mg}$ MVM protein was studied at $37^{\circ} \mathrm{C}$.

Binding to MVM was assessed by a vacuum filtration assay (20). $0.2 \mathrm{ml}$ of the incubation mixtures was rapidly vacuum-filtered on a Whatman GF/C glass filter $(24 \mathrm{~mm}$; Whatman Chemical Separation, Inc., Clifton, NJ) which was quickly washed with $20 \mathrm{ml}$ ice-cold PBS. Washing with more than $20 \mathrm{ml}$ did not change the amount of radioactivity remaining in the filter. The filter was placed in a scintillation vial, $10 \mathrm{ml}$ Econofluor (New England Nuclear) was added, and radioactivity was determined in a liquid scintillation spectrometer (model 3380; Packard Instrument Co., Inc., United Technologies, Downers Grove, IL). Quench correction was determined by a channels ratio method. Recovery of a given amount of ${ }^{14} \mathrm{C}$ was independent of the presence of a filter, as determined by the radioactivity of an unfiltered $0.2-\mathrm{ml}$ aliquot of the incubation mixture. Fatty acid absorption to the filters in the absence of MVM was very reproducible for any given set of experimental circumstances, and constituted $1-4 \%$. The $\left[{ }^{14} \mathrm{C}\right]$ oleate absorbed to the filters without MVM was routinely determined and subtracted from the experimental values. To ensure that the filters did not allow significant quantities of MVM to pass through, aliquots of $100 \mu \mathrm{g}$ MVM protein were applied to filters and washed with $20 \mathrm{ml}$ of PBS. Used as controls, identical aliquots were applied to other filters and placed directly into a test tube without washing. Protein content of both samples was found to be identical $(0.1 \pm 0.07$ $\mathrm{mg}$ ); even after trypsin digestion of MVM $>90 \%$ of the protein was retained on the filter. Binding activity of jejunal basolateral membranes was not examined.
Effect of antibodies on $\left[^{14} \mathrm{C}\right]$ oleate binding to $\mathrm{MVM}$. Aliquots of $0.1 \mathrm{mg} \mathrm{MVM}$ protein were incubated in $240 \mu \mathrm{l}$ PBS for $1 \mathrm{~h}$ at $23^{\circ} \mathrm{C}$ with increasing concentrations of the IgG fractions $(2 \mathrm{mg} / \mathrm{ml})$ of a rabbit antibody to the fatty acid binding membrane protein isolated from rat liver (2) or of anti-rat fibronectin (Calbiochem-Behring Corp., American Hoechst Corp., San Diego, CA). Then $200 \mu \mathrm{l}(1 \mathrm{nmol})$ of $\left[{ }^{14} \mathrm{C}\right]$ oleate/albumin $(1: 1)$ was added and incubated for an additional $5 \mathrm{~min}$. For evaluation of the influence of the antibody on nonspecific binding, heat denatured MVMs were also employed.

Preparation of an oleate agarose affinity column. Oleate-coupled agarose was prepared by incubation of $40 \mathrm{ml}$ swollen, washed AHSepharose 4B (Pharmacia Fine Chemicals, Div. of Pharmacia, Inc., Piscataway, NJ) in $1.5 \mathrm{vol}$ of a $0.1-\mathrm{M}$ solution of the sodium soap of oleic acid at $\mathrm{pH} 10.0 ; 50 \mathrm{mg}$ of 1-ethyl-3(3-dimethyl-aminopropyl)carbodiimide (Sigma Chemical Co.) per millimeter of Sepharose was added, and the mixture was rotated gently for $3 \mathrm{~d}$ at $37^{\circ} \mathrm{C}(2,21)$. The product was washed extensively with $50 \%$ (vol/vol) ethanol, with ethanol/0.075 $\mathrm{M}$ sodium phosphate (1:1), $\mathrm{pH} 2.4$, and with ethanol/ $0.05 \mathrm{~N} \mathrm{NaOH}$ (1:1). Unreacted amino groups were blocked by acetylation with acetic anhydride at $\mathrm{pH} 7.0$ for $1 \mathrm{~h}$.

Isolation of an oleate binding protein from rat jejunal MVM. 500mg MVM proteins were solubilized with $1 \%$ (vol/vol) Triton X-100 (Sigma Chemical Co.) as previously described (22). After centrifugation at $100,000 \mathrm{~g}$ for $60 \mathrm{~min}$, residual detergent was removed from the clear supernatant by passage over a column of Bio-Beads SM2 (BioRad Laboratories, Richmond, CA) (22). The solubilized proteins were then charged onto the oleate-agarose column and washed with PBS at $20 \mathrm{ml} / \mathrm{h}$ until no further protein $\left(\mathrm{OD}_{280}\right)$ appeared in the washes. Then the column was eluted with $7 \mathrm{M}$ urea. All of the above procedures were carried out at $4^{\circ} \mathrm{C}$. The eluate was concentrated by ultrafiltration (Diaflow membranes PM-10; Amicon Corp., Danvers, MA), and the urea dialyzed out with $1 \mathrm{mM} \mathrm{NaHCO}$, $\mathrm{pH}$ 7.6.

Characterization of the oleate binding MVM protein. The protein composition of the urea eluate was characterized by sodium dodecyl sulfate-polyacrylamide gel electrophoresis (SDS-PAGE) on $11 \%$ gels (23). The protein bands were stained routinely with Coomassie Blue (Bio-Rad Laboratories), and representative gels were also stained with Sudan Black and periodic acid-Schiff-stain (24). 0.1-mg aliquots of the isolated oleate binding MVM protein were mixed with tracer doses of ultrasonically dispersed $\left[{ }^{14} \mathrm{C}\right]$ oleate, $\left[{ }^{14} \mathrm{C}\right]$ palmitate $(600 \mathrm{mCi} / \mathrm{mmol})$, $\left[{ }^{14} \mathrm{C}\right]$ arachidonate $(400 \mathrm{mCi} / \mathrm{mmol}),\left[{ }^{14} \mathrm{C}\right]$ linoleate $(600 \mathrm{mCi} / \mathrm{mmol})$, $\left[{ }^{14} \mathrm{C}\right]$ oleate ester of cholesterol $(56.6 \mathrm{mCi} / \mathrm{mmol}),\left[{ }^{14} \mathrm{C}\right] \mathrm{L}-\alpha-1$-palmitoyl, $2-$ oleyl phosphatidylcholine $(57.0 \mathrm{mCi} / \mathrm{mmol})$, all from New England Nuclear, and $\left[{ }^{14} \mathrm{C}\right]$ taurocholate $(43.3 \mathrm{mCi} / \mathrm{mmol})$ or ${ }^{35} \mathrm{~S}-\mathrm{BSP}$. Then the protein-ligand mixtures were subject to gel filtration over a column of Sephadex G-100 (Pharmacia, Inc.), equilibrated with $0.1 \mathrm{M} \mathrm{NaCl} / 1.0$ $\mathrm{mM} \mathrm{NaHCO}, \mathrm{pH} 7.6$, as previously described (2). Elution was carried out with the same buffer at $5 \mathrm{ml} / \mathrm{h}$. Eluates, in $0.5-\mathrm{ml}$ fractions, were monitored for protein at $280 \mathrm{~nm}$ and for radioactivity by liquid scintillation spectrometry as described above.

Purity and specificity of the isolated oleate binding MVM protein was further examined by double immunodiffusion in agar (14) with rabbit antisera against rat albumin, rat serum proteins, ligandin, and the oleate (2) and BSP/bilirubin (22) binding membrane proteins isolated from rat liver. Conversely, the antibody to the oleate binding membrane protein of rat liver was tested against the jejunal and liver fatty acid binding membrane proteins, the rat liver BSP/bilirubin binding membrane protein (22), whole rat serum, and concentrated rat liver as well as rat jejunal cytosols, prepared from the $100,000 \mathrm{~g}$ supernatants of the corresponding homogenates.

Immunofluorescence studies. Frozen sections of esophagus, stomach, jejunum, and colon, with an average thickness of $5 \mu \mathrm{m}$, were air dried. They were incubated for $30 \mathrm{~min}$ at room temperature with rabbit antibody against the oleate binding membrane protein isolated from rat liver, diluted 1:50, 1:100, and 1:200 with PBS, pH 7.4. Sections were washed with PBS for $30 \mathrm{~min}$, then incubated with fluorescein isothiocyanate-conjugated swine anti-rabbit antiserum (Dako, Copenhagen, Denmark) diluted 1:20 or 1:50. After thorough washing with PBS for $60-90 \mathrm{~min}$, sections were mounted with buffered glycerol. 
Controls consisted of incubations with antiserum previously absorbed with the fatty acid binding MVM protein in equal dilution, incubations without immune serum, and incubations with preimmune serum. Sections were examined with a fluorescence microscope (Zeiss, Oberkochen, FRG) using filter combination PB 485, FT 510, LP 520, as previously described (2).

\section{Results}

Characterization of $M V M$ fractions. In numerous randomly analyzed electron micrographs of the MVM fractions employed, only one kind of mostly vesiculated membrane was seen (Fig. 1). Some of the vesicles were filled with electron-dense material, which presumably originated from the core of the microvilli. Contaminating membranes from organelles other than brush borders could not be detected. The pictures resembled those previously published $(9,10)$. Determination of sucrase as a specific marker enzyme for MVM revealed $46.6 \pm 1.6 \mathrm{U} / \mathrm{mg}$ protein sp act in the jejunal MVM fraction as compared with $6.7 \pm 1.8 \mathrm{U} / \mathrm{mg}$ protein sp act in the homogenate. The $5^{\prime}$ nucleotidase was elevated from $4.3 \pm 0.5 \mathrm{U} / \mathrm{mg}$ protein sp act in the homogenate to $23.4 \pm 1.3 \mathrm{U} / \mathrm{mg}$ protein sp act in the jejunal MVM fraction. Contamination with microsomes was assessed by assaying glucose-6-phosphatase $(0.163 \pm 0.016$ vs. $0.440 \pm 0.131 \mathrm{U} / \mathrm{mg}$ protein sp act in the homogenate). Cytoplasmatic and serum protein contamination were not detectable by radial immunodiffusion of the MVM-enriched fraction against antibodies to rat ligandin, transferrin, albumin, and whole rat serum proteins. Antibody preparations against the intestinal cystolic FABP (25) were not available to us.

Membrane binding studies. Since fatty acids self-associate in aqueous solutions at concentrations exceeding $10^{-6}-10^{-5}$ $\mathrm{M}$, membrane binding studies were performed with $\left[{ }^{14} \mathrm{C}\right]$ oleate

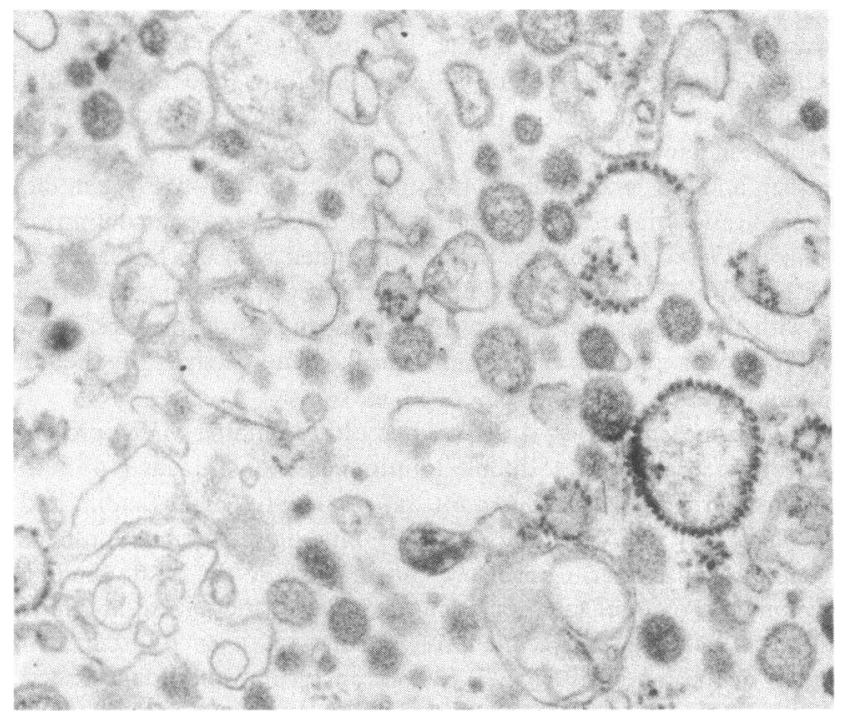

Figure 1. Electron microscopy of representative jejunal MVM preparation. Typical of reported MVM preparations $(9,10)$, the specimen contains a heterogeneous collection of vesicles that vary in shape and amount of electron-dense material within the cavity. There are some membrane fragments that did not vesiculate, and do not enclose a cavity. The surface of many of the vesicles appears rough, and of these, some had a cogwheel appearance, as previously described ( 9 , 10). Some minimal microsomal contamination of the MVM preparation is suggested by both the electron microscopic appearance and the residual glucose-6-phosphatase activity (see text).

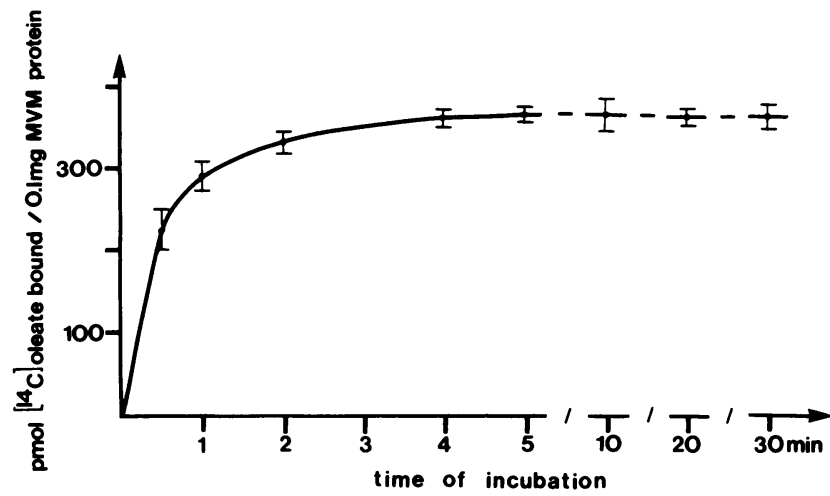

Figure 2. Time course of $\left[{ }^{14} \mathrm{C}\right]$ oleate binding to MVM. $2.272 \mu \mathrm{M}$ $\left[{ }^{14} \mathrm{C}\right]$ oleate bound to albumin $(1: 1)$ was incubated at $23^{\circ} \mathrm{C}$ with aliquots of $0.1 \mathrm{mg}$ MVM protein. Values are means $\pm \mathrm{SD}$ of three replicate experiments.

bound to BSA in various molar ratios. Thus, in accordance with the equilibrium binding constants of albumin-oleate complexes $(18,19)$, the free oleate concentration in the incubation medium could be varied by changing the molar ratio of oleate/albumin while maintaining concentrations of free oleate within the range of solubility. Additional incubation studies were performed with $\left[{ }^{14} \mathrm{C}\right]$ oleate in protein-free aqueous solutions at concentrations lower than $4.6 \times 10^{-6} \mathrm{M}$.

Binding of $\left[{ }^{14} \mathrm{C}\right]$ oleate to aliquots of $0.1 \mathrm{mg}$ MVM protein was rapid. When $2.272 \mu \mathrm{M}\left[{ }^{14} \mathrm{C}\right]$ oleate/albumin $(1: 1)$ was incubated at $23^{\circ} \mathrm{C}$, maximal binding was attained by $3 \mathrm{~min}$ (Fig. 2). Thus, in the subsequent binding studies an incubation time of 5 min was used.

Binding of $\left[{ }^{14} \mathrm{C}\right]$ oleate $(2.272 \mu \mathrm{M}$; oleate/albumin $=1: 10)$ to $\mathrm{MVM}$ as a function of temperature was maximal at $37^{\circ} \mathrm{C}$ (Fig. 3). Influence of different $\mathrm{pH}$ values was determined by incubation of $2.272 \mu \mathrm{M}\left[{ }^{14} \mathrm{C}\right]$ oleate free in aqueous solution so as to avoid concomitant changes in the affinity of oleate for albumin. The overall binding of $\left[{ }^{14} \mathrm{C}\right]$ oleate showed a maximum at $\mathrm{pH} 4$ (Fig. 4). At more physiologic $\mathrm{pH}$ values between 6.8 and 8.0, binding was relatively constant. Binding increased below pH 6.8 and decreased above 8.0. Because of the unusual

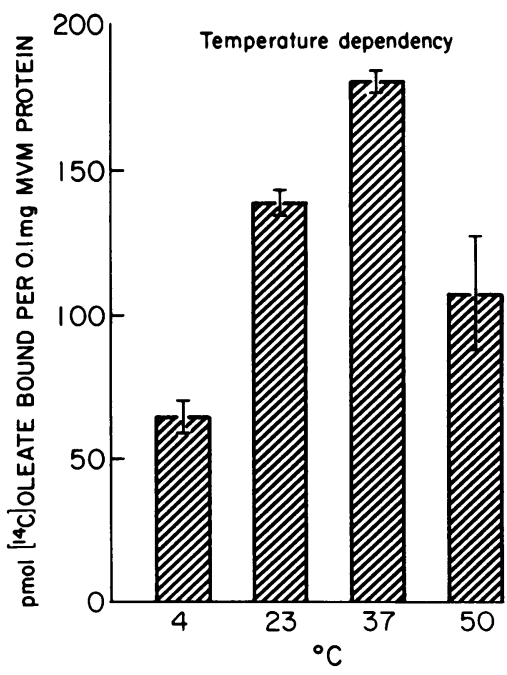

Figure 3. Influence of temperature on binding of $\left[{ }^{14} \mathrm{C}\right]$ oleate to MVM. In these studies, $2.272 \mu \mathrm{M}\left[{ }^{14} \mathrm{C}\right]$ oleate as a $1: 10$ complex with BSA was used. 


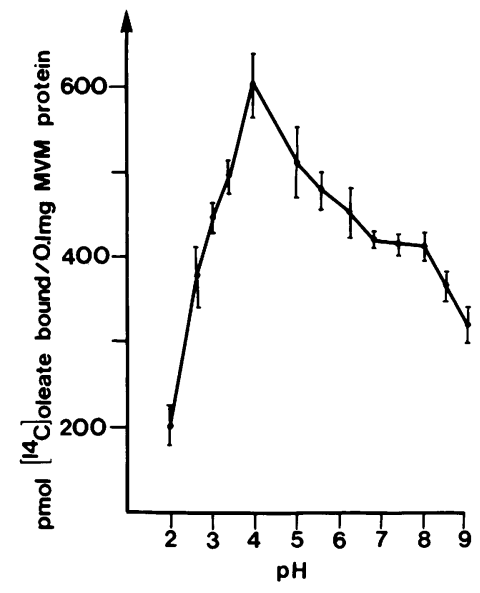

Figure 4. Effect of $\mathrm{pH}$ on binding of $\left[{ }^{14} \mathrm{C}\right]$ oleate to MVM. $2.272 \mu \mathrm{M}$

$\left[{ }^{14} \mathrm{C}\right]$ oleate free in aqueous solution was incubated with aliquots of $0.1 \mathrm{mg} \mathrm{MVM}$ protein in $440 \mu \mathrm{l}$ citratephosphate-borate-/HCl buffer $\mathrm{pH}$ 2-9. Values are means \pm SD of three replicate experiments.

shape of this binding curve, an additional study was performed. Pretreatment of MVM with trypsin did not significantly change binding of $\left[{ }^{14} \mathrm{C}\right]$ oleate $(583.3 \pm 12.7 \mathrm{pmol} / 0.1 \mathrm{mg}$ MVM protein) as compared with native MVM $(602.1 \pm 11.7)$ at $\mathrm{pH} 4.0$. At pH 8.0, however, trypsin reduced binding by $80.3 \%$, from $391.9 \pm 14.9 \mathrm{pmol}$ to $77.2 \pm 7.8 \mathrm{pmol} / 0.1 \mathrm{mg} \mathrm{MVM}$ protein. These different binding characteristics suggest differences in the mechanism of oleate-MVM interaction at these $\mathrm{pH}$ values. The data suggest the possibility that at low $\mathrm{pH}$, the largely nonionized oleic acid molecule binds preferentially to membrane lipids, whereas at physiologic $\mathrm{pH}$, the fatty acid anions bind to a protein binding site.

When $0.455 \mu \mathrm{M}\left[{ }^{14} \mathrm{C}\right]$ oleate/albumin (1:1) was incubated in the presence of a 1,000-fold excess of cold oleate/albumin (1:1), membrane binding of $\left[{ }^{14} \mathrm{C}\right]$ oleate was inhibited by $98.2 \%$, from $67.4 \pm 3.9$ to $1.24 \pm 0.14 \mathrm{pmol} / 0.1 \mathrm{mg} \mathrm{MVM}$ protein. Similarly, incubation of $0.455 \mu \mathrm{M}\left[{ }^{14} \mathrm{C}\right]$ oleate/albumin (1:10) with heat denatured MVM led to an $89 \%$ reduction of binding compared with that observed with native MVM under similar conditions (59.2 \pm 6.0 to $6.5 \pm 1.0 \mathrm{pmol} / 0.1 \mathrm{mg} \mathrm{MVM}$ protein).

In Fig. 5, the quantity of membrane-bound oleate observed in the presence of $4.54 \mu \mathrm{M}\left[{ }^{14} \mathrm{C}\right]$ oleate at various oleate/ albumin molar ratios was plotted as a function of the calculated free oleate concentration in each incubation. When total $\left[{ }^{14} \mathrm{C}\right]$ oleate bound to native MVM was corrected for binding

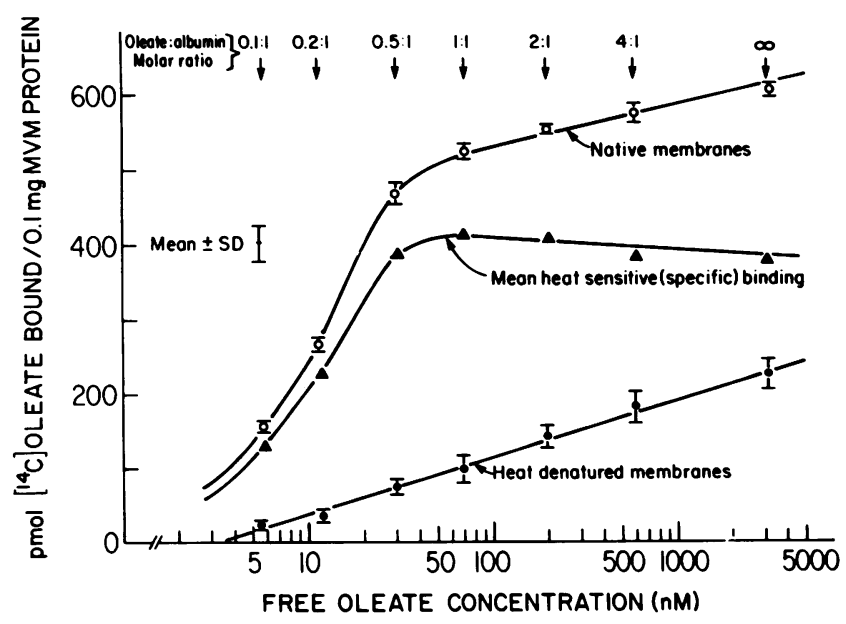

Figure 5. Influence of calculated free oleate concentration on binding of $\left[{ }^{14} \mathrm{C}\right]$ oleate to native and heat denatured jejunal MVM. See text for experimental details. to heat denatured membranes, as an estimate of nonspecific binding, a curve representative of heat sensitive, specific binding was obtained. This curve indicates that heat sensitive binding is saturable, with a dissociation constant $\left(K_{d}\right)=1.6 \times 10^{-8} \mathrm{M}$ and a maximal binding capacity of $460 \mathrm{pmol} / 0.1 \mathrm{mg}$ MVM protein estimated by Scatchard analysis (26).

The data presented above suggest that, as with LPM, binding of $\left[{ }^{14} \mathrm{C}\right]$ oleate to jejunal MVM exhibits the characteristics of specific binding. In contrast to the results with $\left[{ }^{14} \mathrm{C}\right]$ oleate, incubation of $\left[{ }^{35} \mathrm{~S}\right] \mathrm{BSP}$ in the concentration range 0.5-9.1 $\mu \mathrm{M}$, and of $\left[{ }^{14} \mathrm{C}\right]$ taurocholate in the concentration range $0.5-230 \mu \mathrm{M}$, under experimental conditions identical to those used for $\left[{ }^{14} \mathrm{C}\right]$ oleate, did not show any evidence for specific binding to jejunal MVM.

Isolation and characterization of an FABP from MVM. The urea eluate of the oleate agarose affinity chromatography column yielded $1.25 \pm 0.3 \mathrm{mg}(\mathrm{SD})$ protein from the original $500 \mathrm{mg}$ solubilized MVM protein mixture. Compared with the multiplicity of bands it revealed in the initial solution of solubilized membrane proteins, SDS-PAGE showed only a single band of $\sim 40,000 \mathrm{~mol} w \mathrm{wt}$ in the concentrated urea eluate from the oleate-agarose columns (Fig. 6). Rod gels of this oleate binding membrane protein did not stain with either Sudan Black or periodic acid-Schiff-stain. When the oleate binding MVM protein was co-chromatographed over Sephadex G-100 with various organic anions and other hydrophobic membrane constituents, binding to it was demonstrated by all of the various FFA tested (Fig. 7). However, the oleate ester of cholesterol and oleate-containing phosphatidylcholine did not migrate with the protein. $\left[{ }^{35} \mathrm{~S}\right] \mathrm{BSP}$ and $\left[{ }^{14} \mathrm{C}\right]$ taurocholate also were eluted separately from the protein. These data suggest that the oleate binding MVM protein serves as a general free FABP, and that its affinity spectrum is not limited solely to oleate. Moreover, there appears not to be any significant degree of nonspecific binding to lipid membrane constituents other than FFA.

In double immunodiffusion studies, the isolated fatty acid binding MVM protein showed no immunologic activity to antibodies against rat albumin, whole rat serum, ligandin, or the hepatocyte membrane BSP/bilirubin binding protein (22). However, the rabbit antibody against the LPM-FABP (2) showed a single precipitin line of identity between the LPMFABP, the FABP isolated from jejunal MVM, and the solubilized MVM protein mixture. No reactivity was observed between this antibody and rat albumin, whole rat serum, the rat liver BSP/bilirubin binding protein, and concentrated rat liver-as well as jejunal-cytosol (each of which contains a cytosolic FABP).

Antibody inhibition of oleate binding to $M V M$. When 2.272 $\mu \mathrm{M}\left[{ }^{14} \mathrm{C}\right]$ oleate/albumin $(1: 1)$ was incubated at $23^{\circ} \mathrm{C}$ with native MVM in the presence of IgG fractions of antifibronectin, binding remained constant; in the presence of increasing concentrations of anti-LPM-FABP binding progressively decreased (Fig. 8). Binding to heat denatured MVM remained unchanged even in the presence of $400 \mu \mathrm{g}$ of the IgG fraction of LPM-FABP. Antibody inhibition of specific binding (i.e., binding to native MVM minus binding to heat denatured MVM) ranged from 25 to $75 \%$ under these conditions.

Immunofluorescence studies. In frozen sections of rat jejunal mucosa, incubation with the rabbit anti-LPM-FABP before fluorescein-isothiocyanate-conjugated swine anti-rabbit antiserum revealed marked fluorescence of villi and crypts that was limited to the apical parts of brush border cells and to the 


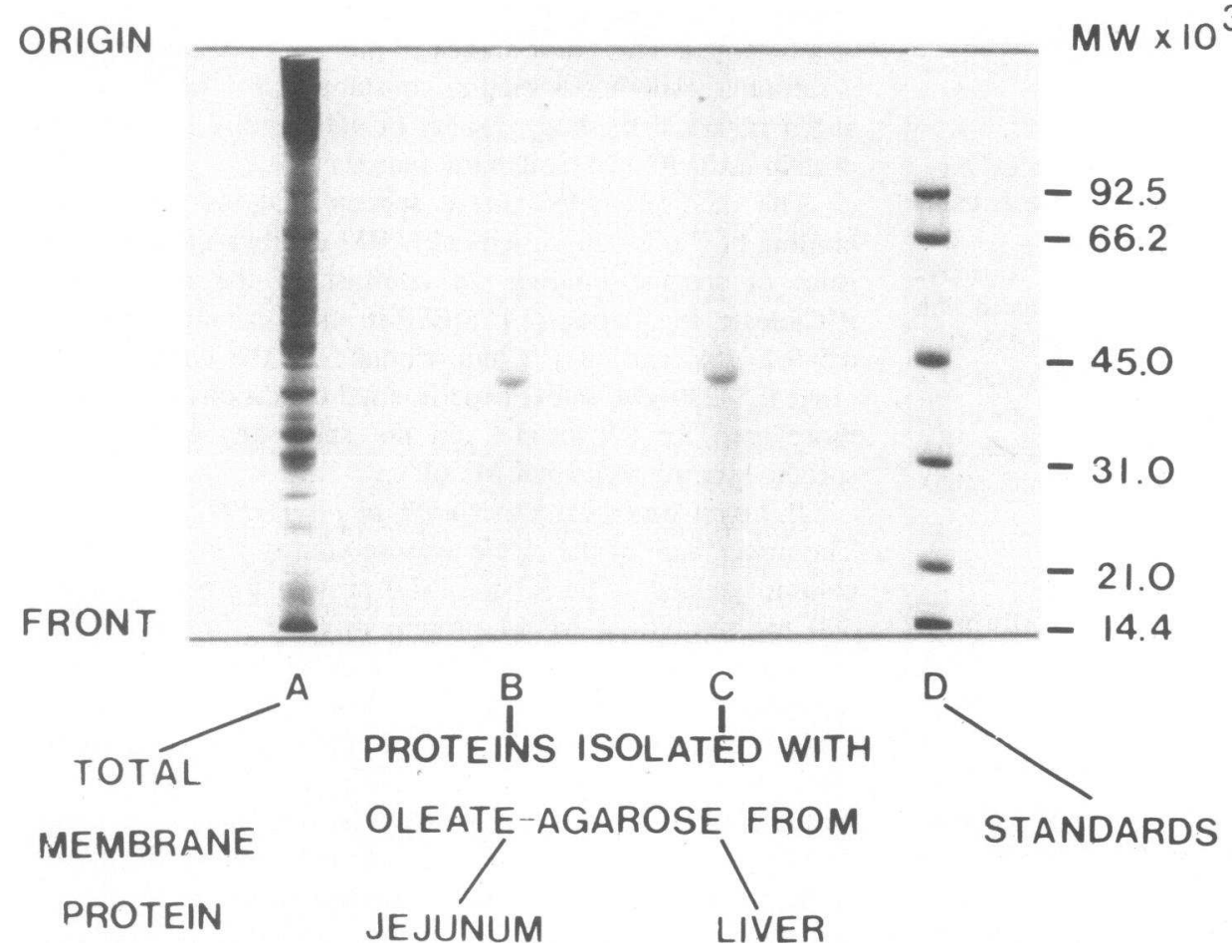

Figure 6. Affinity chromatography of detergent-solubilized proteins from rat jejunal MVM. Figure presents SDS polyacrylamide gel patterns of total solubilized membrane proteins (column $A$ ), and a single band representing the protein $(40,000 \mathrm{~mol} \mathrm{wt})$ eluted from oleate-agarose (column $B$ ). For comparison the 40,000 -mol-wt oleate binding membrane protein isolated from rat liver is shown in column $C$. Molecular weight standards are in column $D$. MW, mol wt.

lateral cell border in the region of the tight junctions. Goblet cells in the crypts did not stain (Fig. 9, $A$ and $B$ ). No fluorescence appeared in any of the control sections. Similar staining, albeit less intense, was observed in the proximal ileum. Frozen sections of the esophagus did not show specific fluorescence. The surface staining observed (Fig. $9 C$ ) was considered to be nonspecific fluorescence because of the keratin of the stratified squamous epithelium, and was equally seen in control sections. In the stomach, faint specific immunofluorescence was found on the surface of some parietal cells, while the remaining mucosal epithelial cells did not show any staining. The mucosa of the colon also did not exhibit specific fluorescence. However, in the submucosa, prominent staining of macrophages was observed (Fig. $9 \mathrm{D}$ ).

\section{Discussion}

The mechanism by which FFA are absorbed from the intestinal lumen is uncertain, although, as with their entry into mammalian cells in general, their initial entry into intestinal epithelial
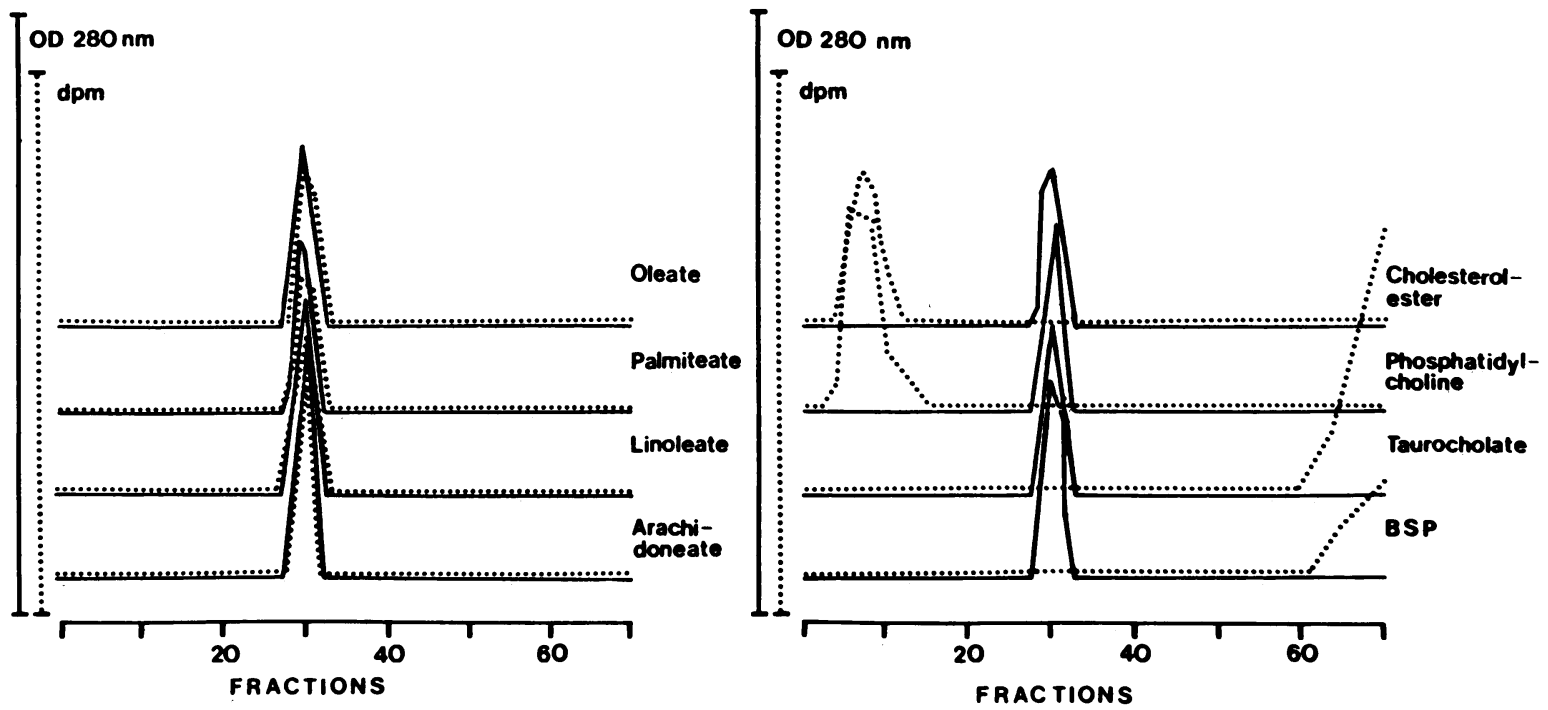

Figure 7. Co-chromatography on Sephadex G-100 of 0.1-mg aliquots of the isolated oleate binding MVM protein with tracer doses of ultrasonically dispersed $\left[{ }^{14} \mathrm{C}\right]$ oleate, $\left[{ }^{14} \mathrm{C}\right]$ palmitate, $\left[{ }^{14} \mathrm{C}\right]$ arachidonate, $\left[{ }^{14} \mathrm{C}\right]$ linoleate, $\left[{ }^{14} \mathrm{C}\right]$ oleate ester of cholesterol, $\left[{ }^{14} \mathrm{C}\right]$ phosphatidylcholine, and $\left[{ }^{14} \mathrm{C}\right]$ taurocholate or $\left[{ }^{35} \mathrm{~S}\right] \mathrm{BSP}$. Only long chain FFA were eluted together with the protein peak. The oleate ester of cholesterol and phosphatidylcholine appeared in the void volume (up to fraction 19), and taurocholate and BSP in the effluent of the column starting at fraction 63. None was associated with protein. See text for experimental details. 

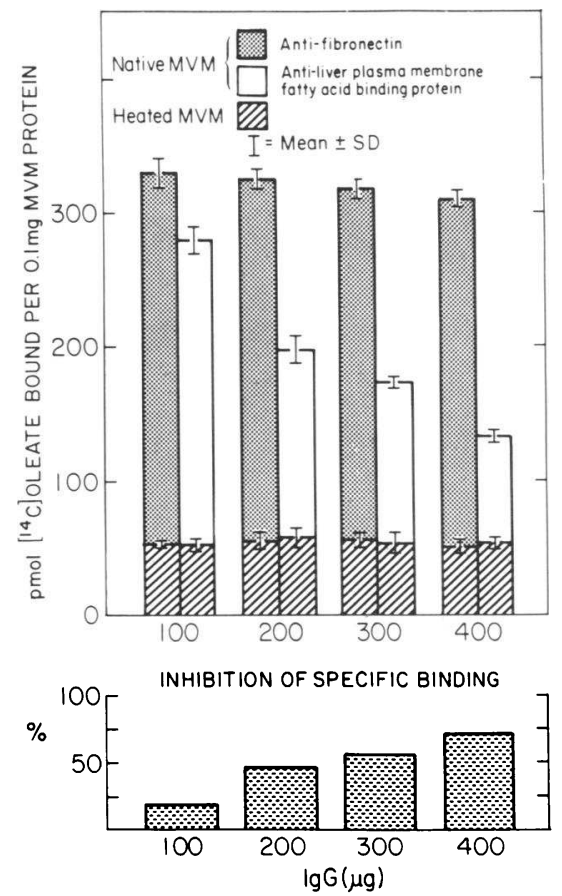

Figure 8. Inhibition of the binding of $\left[{ }^{14} \mathrm{C}\right]$ oleate to MVM by the rabbit antibody to the rat liver fatty acid binding membrane protein. In paired studies aliquots of $0.1 \mathrm{mg}$ of both native and heat denatured MVM protein were incubated with $2.272 \mu \mathrm{M}\left[{ }^{14} \mathrm{C}\right]$ oleate/ albumin $(1: 1)$ at $23^{\circ} \mathrm{C}$ in the presence of increasing concentrations of the IgG fractions of either antifibronectin or anti-LPM-FABP. With increasing concentrations of the anti-LPM-FABP, $\left[{ }^{14} \mathrm{C}\right]$ oleate binding to native MVM progressively decreased, while that to heat denatured MVM was unaffected. Binding to both native and denatured MVM in the presence of antifibronectin remained unchanged. Inhibition of specific $\left[{ }^{14} \mathrm{C}\right]$ oleate binding (i.e., binding to native minus binding to heat denatured MVM) ranged from 25 to $75 \%$ in these studies.

cells has often been described as a passive diffusional process (27). However, more recent studies of a variety of cell types $(3,4,6,7)$, and particularly of adipocytes (5), suggest the existence of a saturable uptake mechanism. An adipocyte membrane protein of $M_{\mathrm{r}}=85,000$ that has an apparent role in fatty acid uptake has been identified by the labeling of membranes with $\left[{ }^{3} \mathrm{H}\right] 4,4^{\prime}$-diisothiocyanostilbene- $2,2^{\prime}$-disulfonate (28). Moreover, data from our own laboratory suggesting that a component of the hepatocellular uptake of FFA was carriermediated and involved a specific FABP in the sinusoidal plasma membrane $(2,8)$, raised the possibility that a similar membrane transport process also mediated their intestinal uptake. The goals of this study, therefore, were to characterize the binding to jejunal MVM of a representative FFA, $\left[{ }^{14} \mathrm{C}\right]$ oleate, and to seek in such MVM a membrane FABP similar to that recently isolated and characterized from the sinusoidal plasma membranes of rat liver (2).

The binding of $\left[{ }^{14} \mathrm{C}\right]$ oleate to MVM was, in fact, shown to be time-, temperature-, and pH-dependent, to be inhibitable and reversible by incubation in the presence of excess cold oleate, and to be markedly reduced by incubation with trypsindigested membranes. Binding was shown to have two components: one, heat resistant, with characteristics of nonspecific binding; and the other, saturable and heat sensitive, with characteristics suggestive of specific binding. In these binding studies, oleate was presented to the MVM in the form of complexes with albumin rather than as aggregates or micelles, as may occur in the intestinal lumen. The incubations therefore represented a nonphysiologic interaction between MVM and the oleate/protein complexes. This disadvantage was offset by the ability to accurately calculate the free oleate concentration in the incubation mixtures, and consequently, to characterize the binding relationship more precisely. Given the extensive binding observed between oleate and MVM in the presence of alternative competing binding sites on albumin, it is most unlikely that MVM would not similarly bind FFAs within the micelle-containing environment of the jejunum.

The binding characteristics observed suggested that specific binding of oleate to MVM was due to an intrinsic membrane protein. This suggestion was pursued by application of an affinity chromatography technique previously successfully employed to demonstrate an FABP in rat liver plasma membranes (2). MVM do, in fact, contain a single 40,000-mol-wt protein with a high affinity for fatty acids, lacking either lipid or carbohydrate components. While the protein's physicochemical similarity to the LPM-FABP was noted, the identity of the two membrane FABPs was confirmed by double immunodiffusion in agar against the antibody to the LPM-FABP. Although we have not yet examined adipocytes, it is possible that the 85,000-mol-wt membrane protein with a fatty acid transport function identified in these cells by Abumrad et al. (28) is a dimeric complex of the 40,000 -mol-wt protein present in hepatocytes and jejunal enterocytes, since the adipocyte protein was identified with membrane-labeling reagents that may serve as bifunctional cross-linking agents. The jejunal membrane FABP does not share immunologic determinants with either ligandin or the cytosolic FABPs previously described in liver (29) and small intestine (25).

The isolated oleate-binding MVM protein revealed in cochromatography studies an affinity for all long chain fatty acids tested, but not for other classes of organic anions or other membrane constituents such as esterified cholesterol and phosphatidylcholine. This suggested that the protein might serve specifically as a general acceptor for FFAs in the gut. Its significance in the binding of fatty acids to jejunal mucosa was further demonstrated by the specific inhibition of $\left[{ }^{14} \mathrm{C}\right]$ oleate binding to MVM by the antibody to the LPM-FABP. Immunohistochemical studies of various parts of the rat gastrointestinal tract revealed the presence of this protein in the upper ileum, but predominantly in the jejunum, the major site of the fatty acid absorption. Consistant with an absorptive function it was localized principally to the apical portion, and to a lesser extent at the lateral cell border in the region of the tight junctions of the brush border cells of the villi. Some staining of the basolateral membranes may, conceivably, reflect a role for the protein in transport of fatty acids out of the epithelial cell for subsequent disposition. An analogous situation occurs in the hepatocyte with respect to the membrane BSP/bilirubin binding protein, which is localized principally to the sinusoidal (basolateral) plasma membrane, but is also identifiable by immunofluorescence in the canalicular (apical) membrane (22). Presence of the MVM-FABP in crypt cells is somewhat unexpected, unless the fatty acid transport system is a primitive mechanism that appears very early in the differentiation and maturation of jejunal enterocytes. There are currently no data to confirm this hypothesis. In contrast to jejunum and ileum, there was no specific staining at the luminal surface of esophagus 

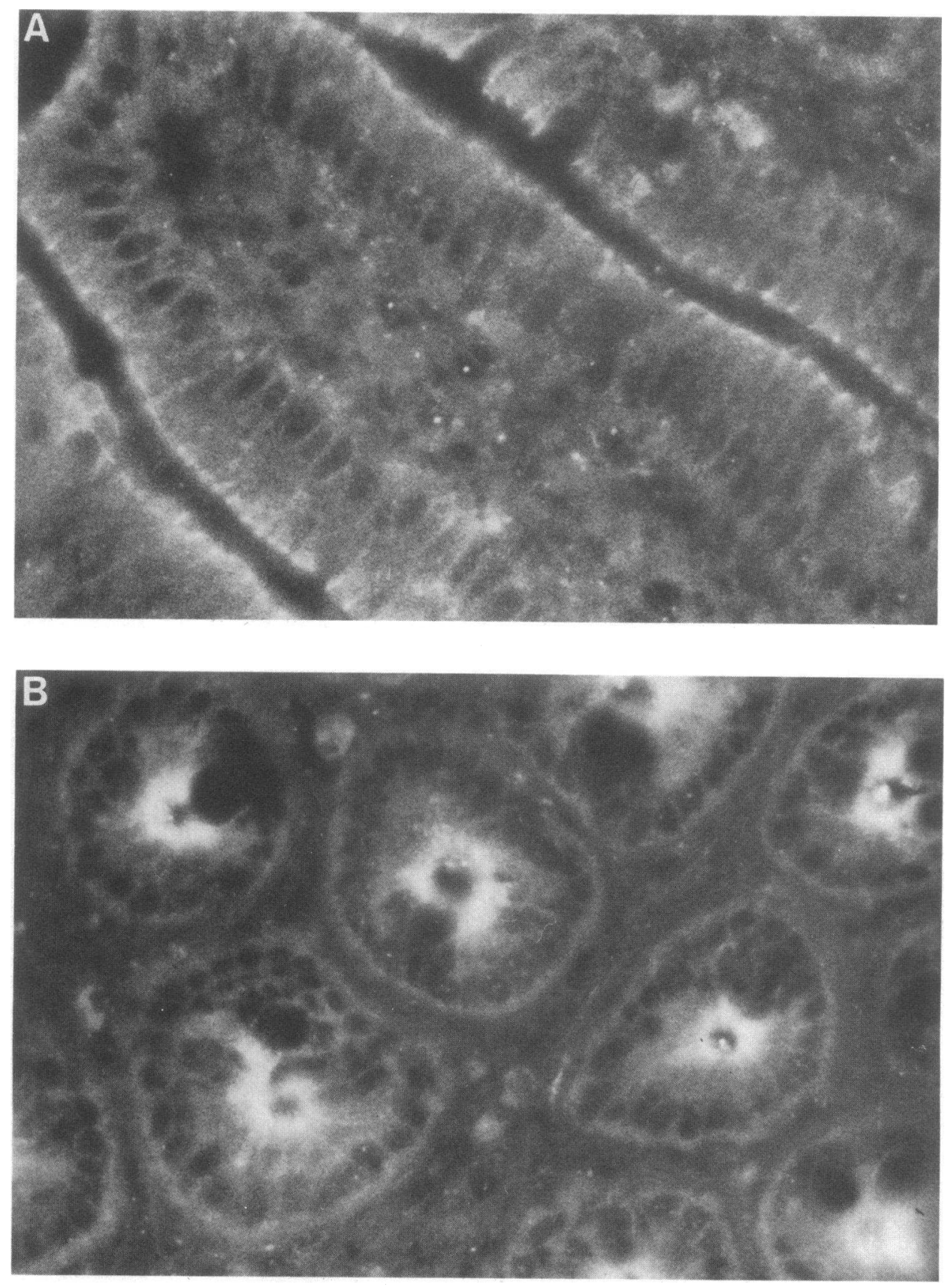

and colon, tissues that are not known to be involved in absorption of fatty acids. However, staining was also observed in some parietal cells of the stomach and in the macrophages of the colon. These cells are known to have high energy requirements, but the specific function of a possible membrane FABP in these cells remains to be determined.

While the estimated $K_{d}$ of both the LPM- $(1,2)$ and MVMFABP/oleate complexes is smaller than that of the oleate/ albumin complex (19), providing a possible explanation for movement of FFA from albumin to the plasma membrane, it is also smaller than the $K_{d}$ of the oleate/cytosolic FABP complex (30). Hence, in an equilibrium system, the relative binding affinities of oleate for albumin, membrane, and cytosolic FABPs would appear to favor accumulation of ligand on the membrane. Similar relative affinities for albumin, membrane binding protein $(22,31)$, and ligandin (29) also exist for BSP and bilirubin. Thus, for both BSP/bilirubin and FFA, transfer from membrane to cytosol presumably reflects a nonequilibrium state resulting from metabolic depletion of the cytosolic ligand pool.

Although specific membrane binding proteins appear to play a role in the hepatocellular uptake of BSP and bilirubin $(22,31)$, conjugated bile acids (32), and certain organic anions such as sulfate (33), the physiologic significance of a specific FABP in hepatocytic plasma membranes and brush border MVM also has yet to be established. Nevertheless, its anatomic location principally in intestinal sites of fatty acid uptake, as well as in liver and myocardium (2), its high affinity for FFA, and the inhibition of fatty acid binding to MVM by antibodies to the protein all argue circumstantially for a significant physiologic role. Observations suggesting that an identical protein in the sinusoidal plasma membrane is involved in the 

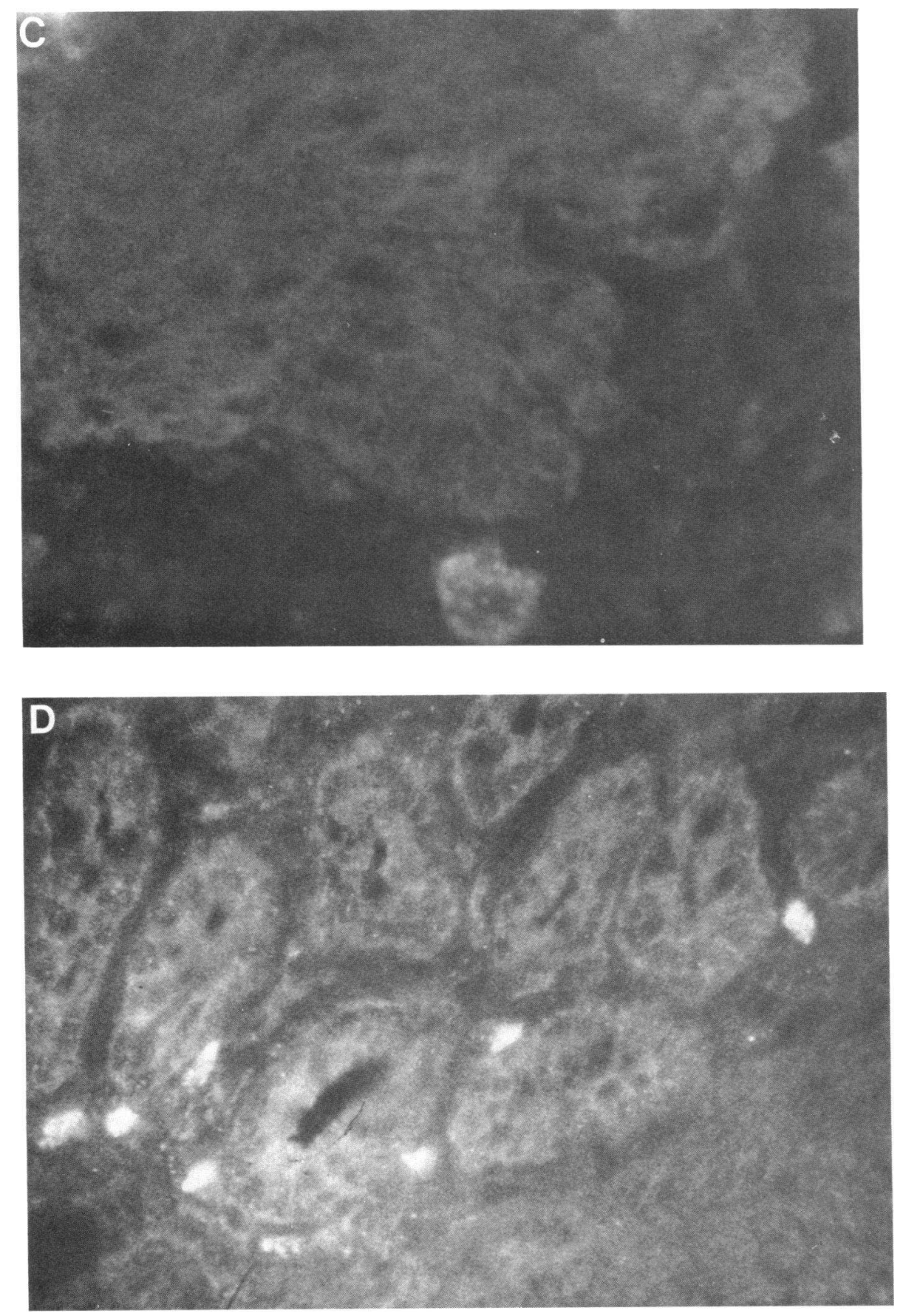

Figure 9. Immunofluorescence studies of different sections of the rat gastrointestinal tract with rabbit antibody to the oleate binding membrane protein from rat liver. In the jejunal mucosa marked fluorescence of villi $(A)$ and crypts $(B)$ is limited to the apical parts of the brush border cells and to the lateral cell border in the region of the tight junctions. Goblet cells in the crypts did not stain. In control sections with antigenabsorbed antibody no fluorescence appeared. Sections of the esophagus do not show specific staining. Nonspecific fluorescence at the surface is due to keratin $(C)$. The colonic mucosa does not exhibit specific immunofluorescence. However, in the submucosa, staining of macrophages is observed $(D)$.

carrier-mediated uptake of FFA by hepatocytes also suggest an analogous function in fatty acid uptake by enterocytes. The implications for regulation of fatty acid metabolism by a carrier-mediated membrane fatty acid transport system are substantial and indicate the need for further studies.

\section{Acknowledgments}

The authors are grateful to Dr. Franz Borchard for the electron microscopic examinations of the jejunal MVM fractions and immunofluorescence microscopic studies of the gut; to Dr. Thomas A. Brasitus for sharing his expertise in the preparation of intestinal brush border MVMs; to Dr. Luis M. Isola for the computer program and calculations of free oleate concentrations in the membrane binding studies; to Dr. Robert Glickman for valuable suggestions; to Ms. Reinhild Hodtke for her excellent technical assistance; and to Ms. Gwen Davis for preparation of the manuscript.

This study was supported by grant STR.216/2-1/2 from the Deutsche Forschungsgemeinschaft, West Germany, and grant AM-26438 from the National Institute of Arthritis, Diabetes, and Digestive and Kidney Diseases, USA.

\section{References}

1. Stremmel, W., S. Kochwa, and P. D. Berk. 1983. Studies of oleate binding to rat liver plasma membranes. Biochem. Biophys. Res. Commun. 112:88-95.

2. Stremmel, W., G. Strohmeyer, F. Borchard, S. Kochwa, and P. D. Berk. 1985. Isolation and partial characterization of a fatty acid 
binding protein in rat liver plasma membranes. Proc. Natl. Acad. Sci. USA. 82.

3. Samuel, D., S. Paris, and G. Ailhaud. 1976. Uptake and metabolism of fatty acids and analogues by cultured cardiac cells from chick embryo. Eur. J. Biochem. 64:583-595.

4. Paris, S., D. Samuel, G. Romey, and G. Ailhaud. 1979. Uptake of fatty acids by cultured cardiac cells from chick embryo: evidence for a facilitation process without energy dependence. Biochimie (Paris). 61:361-367.

5. Abumrad, N. A., R. C. Perkins, J. H. Park, and C. R. Park. 1981. Mechanism of long chain fatty acid permeation in the isolated adipocyte. J. Biol. Chem. 256:9183-9191.

6. Odom, R. E. 1975. Studies on the uptake of free fatty acids by isolated fat cells. Ph.D. thesis. Vanderbilt University, Nashville, TN $115 \mathrm{pp}$.

7. Mahadevan, S., and F. Saver. 1979. Effect of trypsin, phospholipases, and membrane-impermeable reagents on the uptake of palmitic acid by isolated rat liver cells. Arch. Biochem. Biophys. 164:185-193.

8. Stremmel, W., R. Hodtke, G. Strohmeyer, and P. D. Berk. 1984. Hepatocellular uptake of oleate is energy dependent, sodium coupled and inhibited by an antibody to the liver plasma membrane fatty acid binding protein. Hepatology (Baltimore). 4:1067. (Abstr.)

9. Schmitz, J., H. Preiser, D. Maestracci, B. K. Ghosh, J. J. Cerda, and R. K. Crane. 1973. Purification of the human intestinal brush border membrane. Biochim. Biophys. Acta. 323:98-112.

10. Kessler, M., O. Acuto, C. Storelli, H. Murer, M. Muller, and G. Semenza. 1978. A modified procedure for the rapid preparation of efficiently transporting vesicles from small intestinal brush border membranes. Their use in investigating some properties of D-glucose and choline transport systems. Biochim. Biophys. Acta. 506:136-154.

11. Baudhuin, P., P. Evrard, and J. Berthet. 1967. Electron microscopic examination of subcellular fractions. I. The preparation of representative samples from suspensions of particles. J. Cell. Biol. 32:181-191.

12. Fujita, M., H. Matsui, K. Nagano, and M. Nakao. 1971. Asymmetric distribution of ouabain-sensitive ATPase activity in rat intestinal mucosa. Biochim. Biophys. Acta. 233:404-408.

13. Stremmel, W., B. J. Potter, and P. D. Berk. 1983. Studies of albumin binding to rat liver plasma membranes: implications for the albumin receptor hypothesis. Biochim. Biophys. Acta. 756:20-27.

14. Ouchterlony, O. 1958. Diffusion in gel methods. Prog. Allergy. 5:1-78.

15. Lowry, O. H., N. J. Rosebrough, A. Lewis-Farr, and R. J. Randall. 1951. Protein measurement with the Folin phenol reagent. $J$. Biol. Chem. 193:265-279.

16. Chen, R. F. 1967. Removal of fatty acids from serum albumin by charcoal treatment. J. Biol. Chem. 242:173-181.

17. Teorell, T., and E. Stenhagen. 1983. Ein Universalpuffer fur den pH-Bereich 2,0-12,0. Biochem. Z. 299:416-430.

18. Wosilait, W. D., and P. Nagy. 1976. A method of computing drug distribution in plasma using stepwise association constants. Clo- fibrate acid as an illustrative example. Comput. Programs Biomed. 6: 142-148.

19. Spector, A. A., J. E. Fletcher, and J. D. Ashbrook. 1971. Analysis of long chain free fatty acid binding to bovine serum albumin by determination of stepwise equilibrium constants. Biochemistry. 10: 3229-3232.

20. Reichen, J., B. L. Bliltzer, and P. D. Berk. 1981. Binding of unconjugated and conjugated sulfobromophthalein to rat liver plasma membrane fractions in vitro. Biochim. Biophys. Acta. 640:298-312.

21. Peters, T., Jr., H. Taniuchi, and C. B. Anfinsen, Jr. 1972. Affinity chromatography of serum albumin with fatty acids immobilized on agarose. J. Biol. Chem. 248:2447-2451.

22. Stremmel, W., M. A. Gerber, V. Glezerov, S. N. Thung, S. Kochwa, and P. D. Berk. 1983. Physicochemical and immunohistological studies of a sulfobromophthalein- and bilirubin-binding protein from rat liver plasma membranes. J. Clin. Invest. 71:1796-1805.

23. Neville, D. M., Jr. 1971. Molecular weight determination of protein-dodecyl sulfate complexes by gel electrophoresis in a discontinuous buffer system. J. Biol. Chem. 246:6328-6334.

24. Dewald, B., J. T. Dulaney, and O. Touster. 1974. Solubilization and polyacrylamide gel electrophoresis of membrane enzymes with detergents. Methods Enzymol. 32:82-91.

25. Ockner, R. K., and J. A. Manning. 1974. Fatty acid-binding protein in small intestine. Identification, isolation, and evidence for its role in cellular fatty acid transport. J. Clin. Invest. 54:326-338.

26. Scatchard, G. 1949. The attractions of proteins for small molecules and anions. Ann. NY Acad. Sci. 51:660-672.

27. Simmonds, W. J. 1976. Uptake of fatty acid and monoglyceride. In Lipid Absorption: Biochemical and Clinical Aspects. K. Rommel, H. Goebell, and R. Bohmer, editors. MTP Press, Lancaster, England. $51-61$.

28. Abumrad, N. A., J. H. Park, and C. R. Park. 1984. Permeation of long-chain fatty acid into adipocytes. J. Biol. Chem. 259:89458953.

29. Levi, A. J., Z. Gatmaitan, and I. M. Arias. 1969. Two hepatic cytoplasmic protein fractions, $\mathrm{Y}$ and $\mathrm{Z}$, and their possible role in the hepatic uptake of bilirubin, sulfobromophthalein, and other anions. $J$. Clin. Invest. 48:2156-2167.

30. Bass, N. M., J. A. Manning, R. A. Weisiger, and R. K. Ockner. 1984. Binding of endogenous and exogenous fatty acid to hepatic fatty acid binding protein. Hepatology (Baltimore). 4:1016. (Abstr.)

31. Wolkoff, A. W., and C. T. Chung. 1980. Identification, purification and partial characterization of an organic anion binding protein from rat liver cell plasma membrane. J. Clin. Invest. 65:1152-1161.

32. von Dippe, P., and D. Levy. 1983. Characterization of the bile acid transport system in normal and transformed hepatocytes. J. Biol. Chem. 14:8896-8901.

33. Cheng, S., and D. Levy. 1979. Characterization of the anion transport system in hepatocyte plasma membranes. J. Biol. Chem. 7: 2637-2640. 